\title{
Transcription Factor COE4
}

National Cancer Institute

\section{Source}

National Cancer Institute. Transcription Factor COE4. NCI Thesaurus. Code C152988.

Transcription factor COE4 (602 aa, $64 \mathrm{kDa}$ ) is encoded by the human EBF4 gene. This protein is involved in transcriptional regulation, B-cell maturation and neural development. 